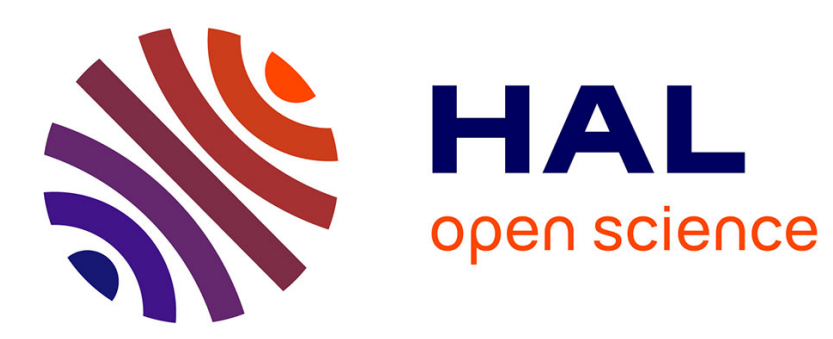

\title{
Preparation of hydrogenated amorphous silicon tin alloys
}

M. Vergnat, G. Marchal, M. Piecuch

\section{To cite this version:}

M. Vergnat, G. Marchal, M. Piecuch. Preparation of hydrogenated amorphous silicon tin alloys. Revue de Physique Appliquée, 1987, 22 (12), pp.1803-1808. 10.1051/rphysap:0198700220120180300 . jpa-00245742

\section{HAL Id: jpa-00245742 https://hal.science/jpa-00245742}

Submitted on 1 Jan 1987

HAL is a multi-disciplinary open access archive for the deposit and dissemination of scientific research documents, whether they are published or not. The documents may come from teaching and research institutions in France or abroad, or from public or private research centers.
L'archive ouverte pluridisciplinaire HAL, est destinée au dépôt et à la diffusion de documents scientifiques de niveau recherche, publiés ou non, émanant des établissements d'enseignement et de recherche français ou étrangers, des laboratoires publics ou privés. 
Classification

Physics Abstracts

$72.80 \mathrm{~N}$

\title{
Preparation of hydrogenated amorphous silicon tin alloys
}

\author{
M. Vergnat, G. Marchal and M. Piecuch \\ Laboratoire de Physique du Solide, U.A. au C.N.R.S. n 155, Université de Nancy-I, B.P. 239, 54506 \\ Vandœuvre Les Nancy Cedex, France
}

(Reçu le $1^{\text {er }}$ juin 1987, révisé le 21 juillet 1987, accepté le $1^{\text {er }}$ septembre 1987)

\begin{abstract}
Résumé. - Ce papier décrit une nouvelle méthode pour obtenir des alliages amorphes semiconducteurs hydrogénés. La méthode que nous utilisons est l'évaporation réactive. Les alliages silicium-étain sont préparés par coévaporation dans une atmosphère d'hydrogène atomique. Nous discutons l'influence des différents paramètres de préparation (pression partielle d'hydrogène, température du tube de tungstène, température du substrat, recuit...) sur les propriétés électriques des échantillons.
\end{abstract}

\begin{abstract}
This paper describes a new method to obtain hydrogenated amorphous semiconductor alloys. The method is reactive co-evaporation. Silicon tin hydrogenated alloys are prepared under atomic hydrogen atmosphere. We discuss the influence of various parameters of preparation (hydrogen pressure, tungsten tube temperature, substrate temperature, annealing...) on electrical properties of samples.
\end{abstract}

\section{Introduction.}

In evaporated amorphous silicon dangling bonds exist. Then, electrical properties are dominated by these dangling bonds and one cannot obtain values as good as those of glow discharge silicon. Several attempts have been made to introduce atomic hydrogen in evaporated silicon in order to achieve the saturation of dangling bonds. Kaplan et al. [1] performed post hydrogenation of evaporated films by diffusing atomic hydrogen from r.f. and d.c. plasma. However, this method does not permit to introduce a uniform concentration of hydrogen in the films and the plasma tends to erode film surface leading to inhomogeneity in samples thickness.

Thus, several groups have tried to hydrogenate samples during evaporation. Dellafera et al. [2] evaporated silicon in a plasma of hydrogen produced near the substrates. The $\mathrm{H}_{2}$ molecules were splitted into atomic hydrogen by applying high voltage with a Penning-like configuration of electrodes. Gangopadhyay et al. [3] utilized a microwave discharge tube. Grasso et al. [4] and Shindo et al. [5] dissociated hydrogen with ion guns. But ion guns provide mixture of $\mathrm{H}^{+}$and $\mathrm{H}_{2}^{+}$with unknown $\mathrm{H}^{+} / \mathrm{H}_{2}^{+}$ratio and the ions have relatively high energy and thus they may produce radiation damage in films. Miller et al. [6] and Viturro et al. [7] cracked $\mathrm{H}_{2}$ gas in a heated tungsten tube at high temperature.
Our final goal is to produce good hydrogenated amorphous silicon tin alloys. Amorphous silicon tin alloys are attractive due to their potential applications in multiband gap solar cells structures because relatively narrow gap can be obtained with low tin contents [8].

Up to now hydrogenated amorphous silicon tin alloys have mainly be prepared by sputtering $[9,10]$, sputtering assisted plasma chemical vapour deposition [11] or glow discharge [12, 13]. However these techniques do not allow preparation of very pure specimens ; tin hydride does not exist (stable) and one has to use $\mathrm{Sn}\left(\mathrm{CH}_{3}\right)_{4}$ or $\mathrm{SnCl}_{4}$, inducing carbon or chlorine contamination of samples.

We have previously shown that co-evaporation is a suitable method to prepare amorphous $\mathrm{Si}_{1-x} \mathrm{Sn}_{x}$ alloys [14]. Substrates were maintained at liquid nitrogen temperature in order to prevent $\beta$ tin precipitation. $\mathrm{Si}_{1-x} \mathrm{Sn}_{x}$ amorphous alloys are obtained from $x=0$ to $x=0.75$. As shown by electron diffraction and micrography, the samples are homogeneous for $x<0.5$; for $x$ between 0.5 and $0.75 \beta$ tin precipitates coexist with amorphous silicon tin matrix.

This paper has then three goals :

i) describing our experimental set-up,

ii) discussing the influence of preparation parameters (hydrogen pressure, substrate temperature, 
dissociator temperature) on the incorporation of atomic hydrogen in films. Pure silicon was chosen as test material for this purpose.

iii) giving first results on properties of hydrogenated silicon tin alloys (dark conductivity measurements).

\section{Experimental method.}

2.1 Evaporation CHAMBER. - Samples are prepared in ultrahigh vacuum system (Fig. 1) pumped with a cryogenerator. The chamber is outgassed at $150{ }^{\circ} \mathrm{C}$ during $12 \mathrm{~h}$. Ultimate pressure is less than $10^{-8}$ Torr. Tin and silicon are evaporated from a thermal cell and an electron beam gun respectively. Two quartz monitoring systems regulate the deposition rates of each constituent. Deposition rates are typically between 2 and $5 \AA / s$.
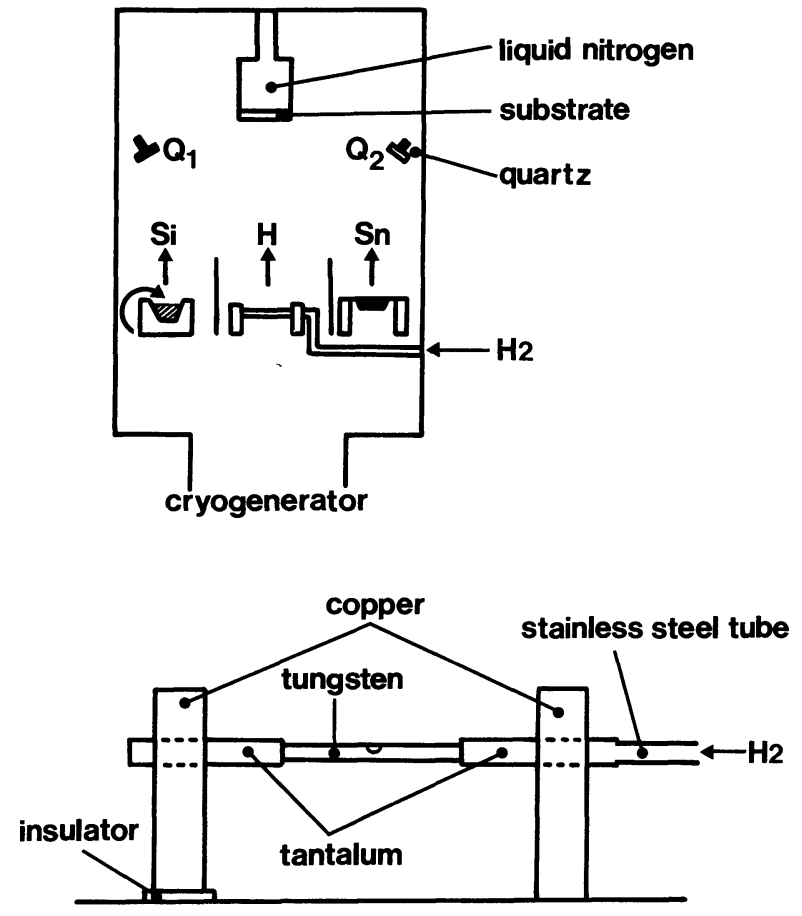

Fig. 1. - Schematic diagram of the evaporation chamber and of the dissociator.

2.2 Hydrogenation method. - Atomic hydrogen is introduced in the film during the co-evaporation of silicon and tin. Atomic hydrogen beam is produced by thermal dissociation of molecular hydrogen (see Fig. 1b). Dissociation is accomplished by passing a flow of molecular hydrogen through a $1 \mathrm{~mm}$ inner diameter tungsten tube heated by Joule effect at temperature larger than $2200 \mathrm{~K}$. Tube temperature is measured with an optical pyrometer. Atomic hydrogen passes into reaction chamber through a small aperture looking over the substrate ; the substrate-aperture distance is equal to the evap- oration source-substrate distance of $30 \mathrm{~cm}$. Atomic hydrogen flow is regulated indirectly by maintaining the chamber pressure at a fixed value (feed-back loop between ionization gauge and hydrogen valve). The maximal operating pressure is $10^{-4}$ Torr. This pressure corresponds to a mean free path of about one meter. Thus, hydrogen is always in a molecular flow. The dissociation ratio $x=\mathrm{H} / \mathrm{H}_{2}$ is plotted in figure 2 versus pressure for different dissociator temperatures $T_{\mathrm{D}}[15]$.

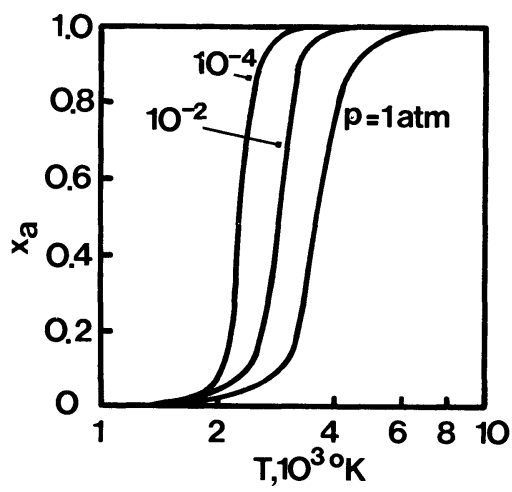

Fig. 2. - The mole fraction of atomic hydrogen $x_{\mathrm{a}}$ as a function of temperature in an equilibrium mixture of atomic and molecular hydrogen at several pressures.

$x$ is large when the unknown pressure inside the tungsten tube $P_{\mathrm{T}}$ is low, but atomic hydrogen flow is proportional to $P_{\mathrm{T}}$ and a compromise must certainly be found.

A fraction of atomic hydrogen flow meets substrate and is incorporated in films; other atoms recombinate on chamber walls. Measured chamber pressure $P$ corresponds to this molecular hydrogen. $D$ depends on the pumping speed, on the tube aperture conductance and on the pressure $P_{\mathrm{T}}$ (an estimation of $P_{\mathrm{T}}$ gives values lower than 1 Torr which corresponds to $x=0.7$ at $2650 \mathrm{~K}$ ). For a total pressure $P$ of $10^{-4}$ Torr, an estimation of atomic hydrogen rate of deposition (with a sticking coefficient equal to unity) gives $10^{15}$ atoms $/ \mathrm{cm}^{2}$ similar to the deposition rate of silicon atoms. However, hydrogen molecules which strike the substrates are of order of $10^{17}$ atoms $/ \mathrm{cm}^{2}$. In fact, it is probable that the sticking coefficient of hydrogen atoms and molecules are very different and certainly lower than unity.

2.3 Conductivity measurements. - It is easily shown [16] that in the planar configuration, conductivity measurements give results which are extremely sensitive to band bending at the surfaces of the film. On the other hand, the "sandwich » configuration, where the electrodes are on each side of the film, presents difficult electrode problems. 
For a first characterization of films and to compare their conductivity, we carry out the D.C. dark conductivity measurements in situ with planar configuration. Chromium contacts are predeposited onto the glass substrates. The distance between electrodes is $10 \mathrm{~mm}$. Samples thickness are about $1000 \AA$. A picoammeter allows measurement of resistances as large as $10^{14} \Omega$ with a guarded method. (The output voltage is $10 \mathrm{~V}$.) Substrates temperature can vary between $77 \mathrm{~K}$ and $500 \mathrm{~K}$. Annealing procedure consists to heat until annealing temperature $T_{\mathrm{A}}$ is reached and to cool down the samples immediately. Cooling and heating rates are $2 \mathrm{~K} / \mathrm{min}$.

\section{Experimental parameters.}

3.1 INTEREST OF THE DISSOCIATION. - We evaporated amorphous silicon samples within three different conditions :

i) without hydrogen,

ii) with molecular hydrogen $P=4 \times 10^{-5}$ Torr (dissociator cold),

iii) with atomic hydrogen $P=4 \times 10^{-5}$ Torr (dissociator heated at $T_{\mathrm{D}}=2400 \mathrm{~K}$ ).

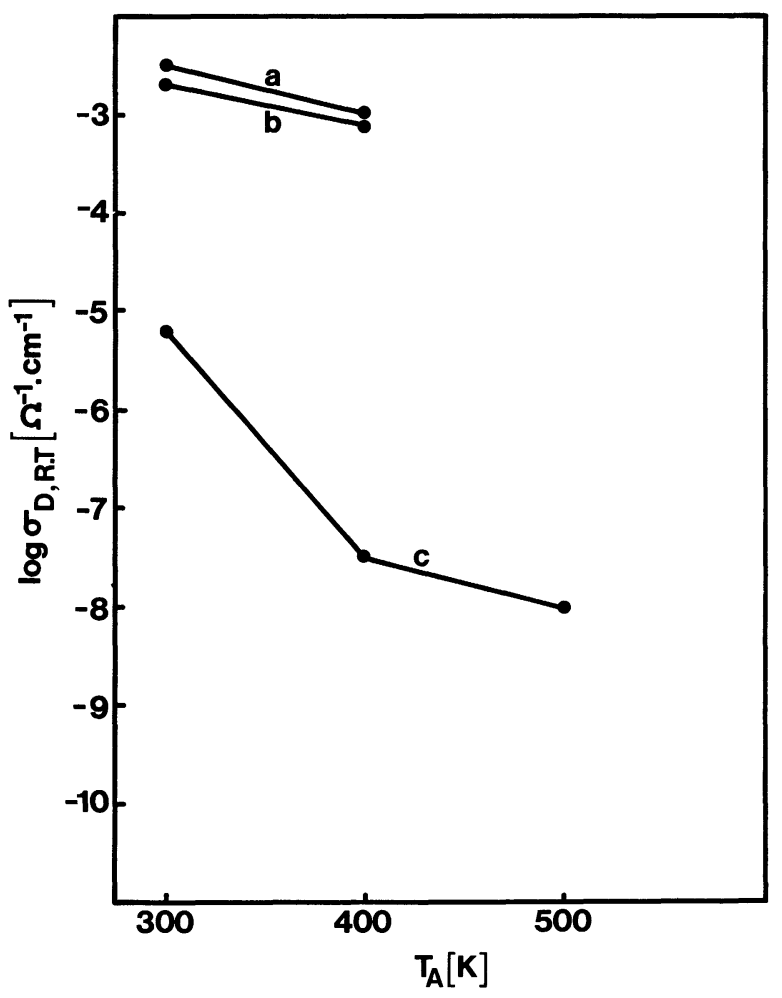

Fig. 3. - Interest of the dissociator : dark conductivity at room temperature of amorphous silicon as a function of annealing temperature $T_{\mathrm{A}}$. The substrate temperature is $300 \mathrm{~K}$ : a) without hydrogen, b) molecular hydrogen $P=4 \times 10^{-5}$ Torr, c) «atomic » hydrogen $P=4 \times$ $10^{-5}$ Torr $; T_{\mathrm{D}}=2400 \mathrm{~K}$.
We compared their room temperature dark conductivity $\sigma_{D, \text { R.T. }}$ as a function of different annealing temperatures $T_{\mathrm{A}}$. As shown in figure 3 , molecular hydrogen does not practically modify conductivity. However, as soon as the dissociator is heated, $\sigma_{\text {D, R.T. }}$ decreases by several orders of magnitude. The difference is still larger after the thermal treatments.

3.2 SubSTRATE TEMPERATURE. - The substrate temperature $T_{\mathrm{S}}$ is, in general, an important parameter. Hydrogen concentration inside films and relative proportion of monohydride and dihydride depends on $T_{\mathrm{S}}$. We evaporated samples at two substrate temperatures : $77 \mathrm{~K}$ and $300 \mathrm{~K}$ (Tab. I). Conductivity is a little bit lower when samples are prepared at $77 \mathrm{~K}$. However effects of annealing treatments are very similar.

Table I. - Influence of $T_{\mathrm{S}}$. Room temperature dark conductivity $\sigma_{\mathrm{D}, \mathrm{R} . \mathrm{T} .}\left(\Omega^{-1} \cdot \mathrm{cm}^{-1}\right)$ versus annealing temperature $T_{\mathrm{A}}$ for a-Si samples prepared with different substrate temperatures $T_{\mathrm{S}}\left(P_{\mathrm{H}_{2}}=4 \times 10^{-5}\right.$ Torr, $\left.T_{\mathrm{D}}=2400 \mathrm{~K}\right)$.

\begin{tabular}{|c|c|c|c|}
\cline { 2 - 4 } \multicolumn{1}{c|}{} & $T_{\mathrm{A}}=300 \mathrm{~K}$ & $T_{\mathrm{A}}=400 \mathrm{~K}$ & $T_{\mathrm{A}}=500 \mathrm{~K}$ \\
\hline$T_{\mathrm{S}}=77 \mathrm{~K}$ & $3.5 \times 10^{-7}$ & $1.0 \times 10^{-8}$ & $2.2 \times 10^{-9}$ \\
$T_{\mathrm{S}}=300 \mathrm{~K}$ & $6.3 \times 10^{-6}$ & $3.1 \times 10^{-8}$ & $1.0 \times 10^{-8}$ \\
\hline
\end{tabular}

3.3 DisSociator TEMPERATURE. - Samples were prepared at different temperatures $T_{\mathrm{D}}=2200$, 2400 and $2650 \mathrm{~K}$ (Tab. II). The other experimental conditions remained the same. As expected, conductivity decreases with $T_{\mathrm{D}}$; but, beyond $T_{\mathrm{D}} \simeq 2400 \mathrm{~K}$, the variation of conductivity with $T_{\mathrm{A}}$ becomes smaller and for $T_{\mathrm{D}} \simeq 2650 \mathrm{~K}$ the influence of annealing seems to disappear.

Table II. - Influence of $T_{\mathrm{D}}$. Room temperature dark conductivity $\sigma_{D, \text { R.T. }}\left(\Omega^{-1} \cdot \mathrm{cm}^{-1}\right)$ versus annealing temperature $T_{\mathrm{A}}$ for a-Si samples prepared with different dissociator temperatures $T_{\mathrm{D}}\left(P_{\mathrm{H}_{2}}=4 \times\right.$ $10^{-5}$ Torr, $\left.T_{\mathrm{S}}=77 \mathrm{~K}\right)$.

\begin{tabular}{|l|l|l|l|}
\cline { 2 - 4 } \multicolumn{1}{c|}{} & $T_{\mathrm{A}}=300 \mathrm{~K}$ & $T_{\mathrm{A}}=400 \mathrm{~K}$ & $T_{\mathrm{A}}=500 \mathrm{~K}$ \\
\hline$T_{\mathrm{D}}=2200 \mathrm{~K}$ & $1.0 \times 10^{-4}$ & $1.0 \times 10^{-6}$ & $3.2 \times 10^{-8}$ \\
$T_{\mathrm{D}}=2400 \mathrm{~K}$ & $4.0 \times 10^{-7}$ & $1.0 \times 10^{-8}$ & $2.0 \times 10^{-9}$ \\
$T_{\mathrm{D}}=2650 \mathrm{~K}$ & $1.0 \times 10^{-8}$ & $2.5 \times 10^{-9}$ & $6.3 \times 10^{-10}$ \\
\hline
\end{tabular}

3.4 HydROGEN PARTIAL PRESSURE. - Theoretically, influence of hydrogen partial pressure is not very 
clear, but experimentally one can see in table III that the higher pressure, $P=10^{-4}$ Torr, corresponds to the lower conductivity.

Table III. - Influence of $P_{\mathrm{H}_{2}}$. Room temperature dark conductivity $\sigma_{\mathrm{D} \text {, R.T. }}\left(\Omega^{-1} \cdot \mathrm{cm}^{-1}\right)$ versus annealing temperature $T_{\mathrm{A}}$ for a-Si samples prepared with different hydrogen pressures $\left(T_{\mathrm{D}}=2400 \mathrm{~K}, T_{\mathrm{S}}=\right.$ $77 \mathrm{~K})$.

\begin{tabular}{|l|l|l|l|}
\cline { 2 - 4 } \multicolumn{1}{l|}{} & $T_{\mathrm{A}}=300 \mathrm{~K}$ & $T_{\mathrm{A}}=400 \mathrm{~K}$ & $T_{\mathrm{A}}=500 \mathrm{~K}$ \\
\hline$P=10^{-5}$ Torr & $7.9 \times 10^{-6}$ & $3.2 \times 10^{-7}$ & \\
$P=4 \times 10^{-5}$ Torr & $4.0 \times 10^{-7}$ & $1.0 \times 10^{-8}$ & $1.8 \times 10^{-9}$ \\
$P=10^{-4}$ Torr & $1.0 \times 10^{-7}$ & $3.2 \times 10^{-9}$ & $6.3 \times 10^{-10}$ \\
\hline
\end{tabular}

In all these experiments, the base pressure is always less than $10^{-8}$ Torr. We do not think that oxygen contamination is responsible of the decrease of conductivity versus pure hydrogen pressure. However, the porosity of films certainly varies with pressure and it can modify the results of conductivity.

3.5 COMPARISON WITH PREVIOUS RESUlTS ON AMORPHOUS SILICON. - Although, dark conductivity is, perhaps, not the best criterion for film quality ; a comparison with values obtained by other groups may be instructive. These values are between $10^{-8} \Omega^{-1} \mathrm{~cm}^{-1}[2,4]$ and $10^{-11} \Omega^{-1} \mathrm{~cm}^{-1}[3,5]$ for films deposited or annealed at temperature higher than $500 \mathrm{~K}$. The lowest value we obtain $\left(10^{-9} \Omega^{-1} \mathrm{~cm}^{-1}\right)$ is well between these extreme values, but our samples conductivity could decrease if samples were annealed above $500 \mathrm{~K}$.

\section{4. a SiSn : H alloys.}

4.1 Structure AND STABILITY. - As said in introduction, substrates were maintained at $77 \mathrm{~K}$ in order to avoid risk of segregation. Dissociator temperature was fixed at $T_{\mathrm{D}}=2400 \mathrm{~K}$ and hydrogen pressure at $P=10^{-4}$ Torr. Under these experimental conditions, samples tin contents varied from 0 to $50 \%$. At room temperature, electron diffraction and micrograph showed that samples were still amorphous and did not contain $\beta$ tin precipitates in the whole composition range.

As shown in figure 4, crystallization temperatures $T_{\text {cr }}$ are determined from the point, $C$, where resistance rapidly drops. Insert of figure 7 represents the composition dependence of $T_{\text {cr }}$ for $0.5 \leqq x \leqq 0.6$. The obtained values are very similar to those measured for non-hydrogenated alloys [14]. Crystallization products are always crystallites of silicon and $\beta$ tin.

4.2 Conductivity measurements. - Dark conductivity of $a \mathrm{Si}_{1-x} \mathrm{Sn}_{x}$ and $a \mathrm{Si}_{1-x} \mathrm{Sn}_{x}: \mathrm{H}$ alloys

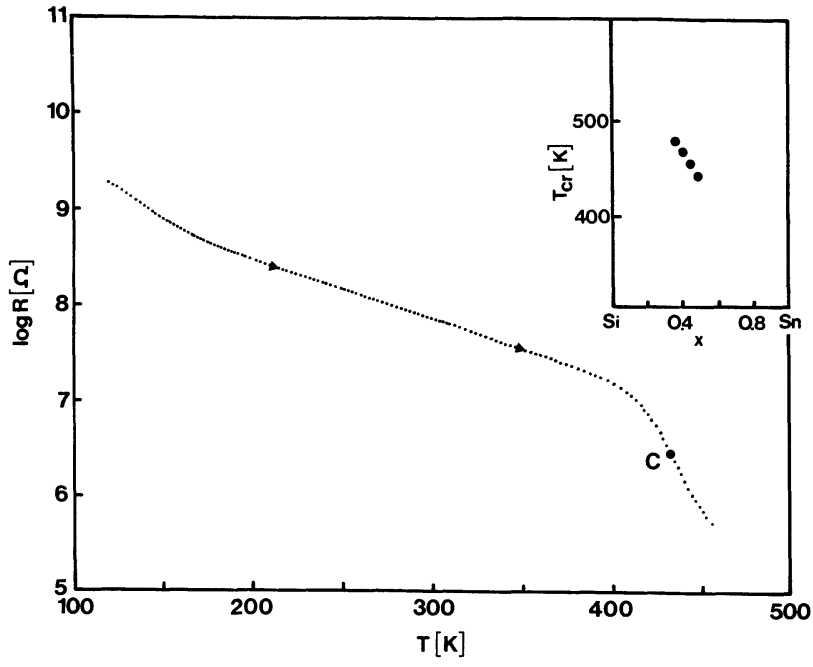

Fig. 4. - Variation of the resistance of the $\mathrm{Si}_{55} \mathrm{Sn}_{45}: \mathrm{H}$ alloy as a function of temperature. The point labelled $C$ determines the crystallization temperature $T_{\mathrm{cr}}$. The insert represents $T_{\text {сr }}$ for different tin concentrations.

annealed at room temperature is represented in figure 5, versus composition $x$. Values obtained for hydrogenated samples $\left(P=10^{-4} \mathrm{Torr}, T_{\mathrm{S}}=77 \mathrm{~K}\right.$, $\left.T_{\mathrm{D}}=2400 \mathrm{~K}\right)$ are several orders of magnitude lower than those obtained for non-hydrogenated samples

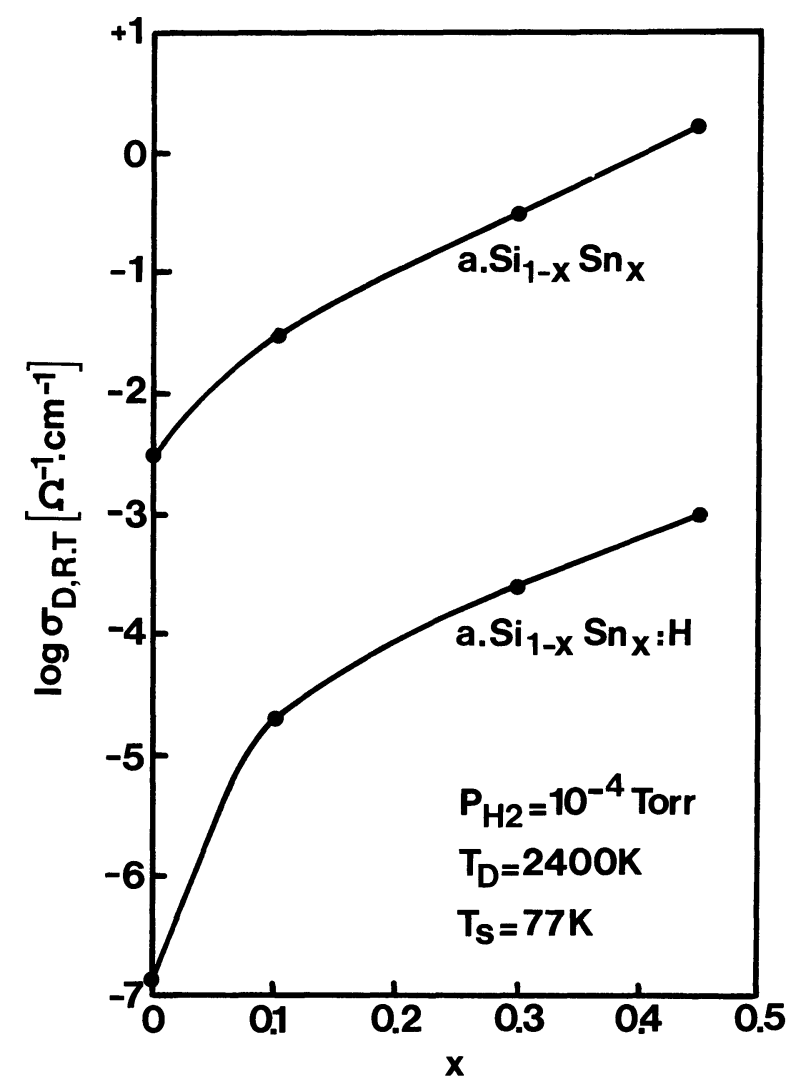

Fig. 5. - Variation of the room temperature dark conductivity with tin content $x$ for a $\mathrm{Si}_{1-x} \mathrm{Sn}_{x}$ and a $\mathrm{Si}_{1-x} \mathrm{Sn}_{x}: \mathrm{H}$ alloys $\left(T_{\mathrm{A}}=300 \mathrm{~K}\right)$. 
in the whole composition range. Figure 6 shows the influence of annealing temperature for different composition. One can see that for $x \geqq 0.28$, the conductivity remains almost constant. However, annealing treatments are limited by crystallization temperature.

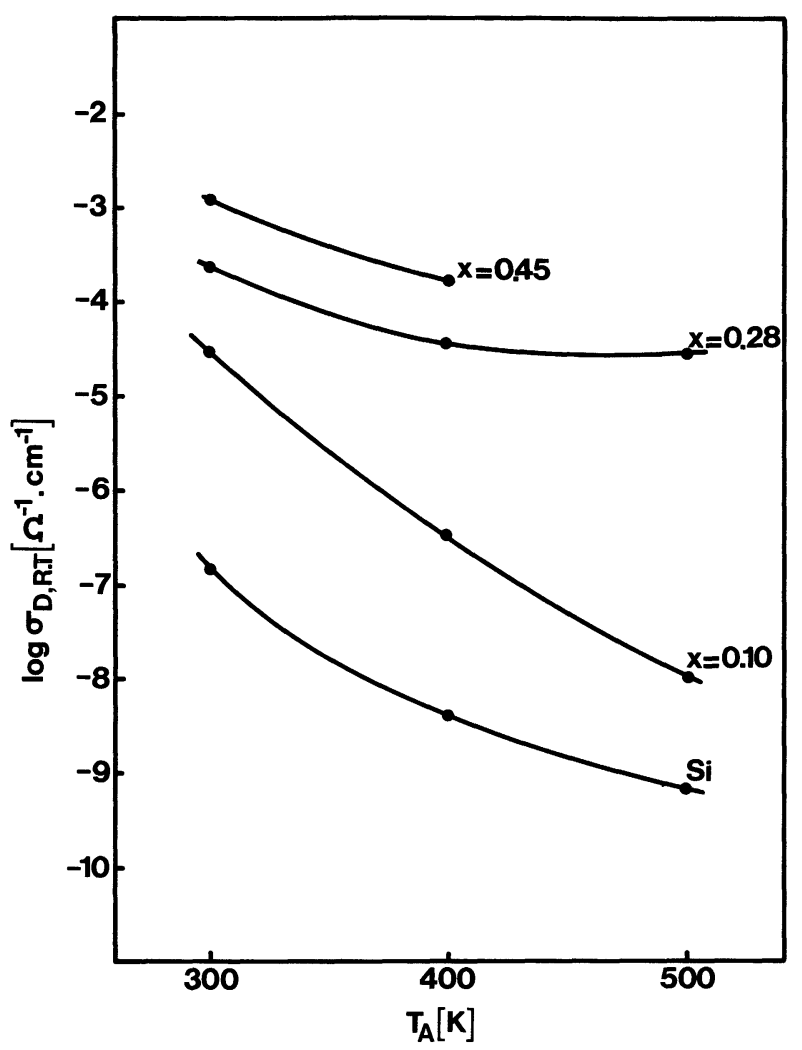

Fig. 6. - Room temperature dark conductivity as a function of annealing temperature $T_{\mathrm{A}}$ for different $a$ $\mathrm{Si}_{1-x} \mathrm{Sn}_{x}: \mathrm{H}$ alloys.

The temperature dependence of dark conductivity was measured between $200 \mathrm{~K}$ to $300 \mathrm{~K}$ when $T_{\mathrm{A}}$ was $300 \mathrm{~K}$ and between $300 \mathrm{~K}$ and $T_{\mathrm{A}}$ for $T_{\mathrm{A}}=400 \mathrm{~K}$ or $500 \mathrm{~K}$. The temperature behaviour is apparently activated and we have plotted in figure 7 the activation energy $E_{\mathrm{A}}$ (slope of $\log \sigma_{\mathrm{D}}$ versus $1 / T)$ versus composition $x$. Activation energies are rather high for low tin contents but drop to around $0.3 \mathrm{eV}$ for $x \geqq 0.2$.

The values of activation energies in the rich silicon side are consistent with extended states conduction, but values for $x \geqq 0.2$ are rather low and close to those obtained for heavily doped $a \mathrm{Si}: \mathrm{H}$ and undoped $a \mathrm{Si}$; they are often associated with variable range hopping. In agreement with Williamson et al. $[17,18]$ it seems that $a \mathrm{SiSn}: \mathrm{H}$ alloys exhibit transition from extended to localized state conduction near $x \simeq 0.2$. A second interpretation can be proposed. Indeed, the apparition of a high density of gap states can shift the Fermi level towards positive

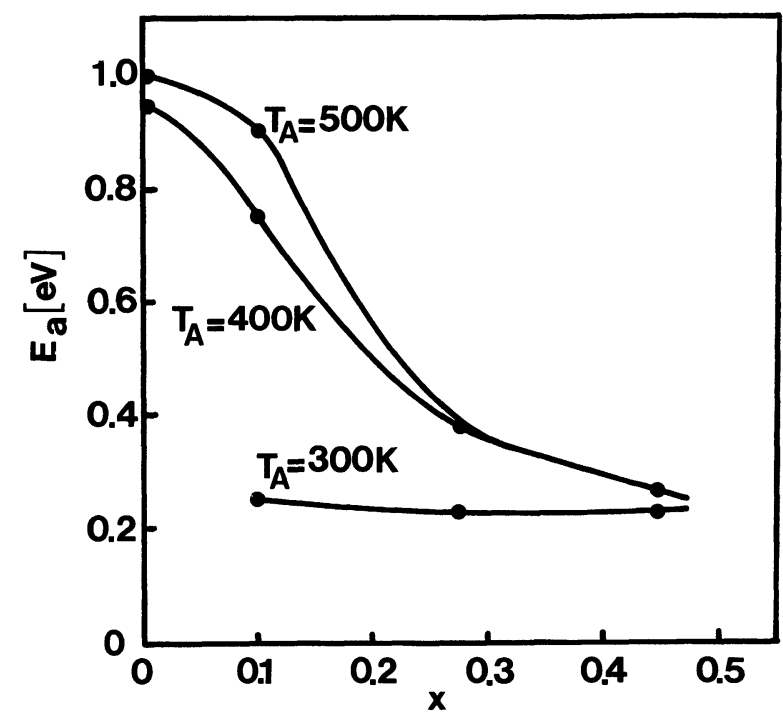

Fig. 7. - Activation energy as a function of tin content for a $\mathrm{Si}_{1-x} \mathrm{Sn}_{x}: \mathrm{H}$ alloys. $T_{\mathrm{A}}$ is the annealing temperature.

energies and decrease the activation energy to low values.

\section{Conclusion.}

It has been shown in this paper that hydrogenation of silicon tin alloys is possible by activated reactive co-evaporation on substrates cooled at $77 \mathrm{~K}$.

This method allows to incorporate hydrogen in the films and to obtain samples of pure silicon with $\sigma_{\text {D, R.T. }}$ less than $10^{-9} \Omega^{-1} \mathrm{~cm}^{-1}$, which is a value comparable to those obtained by other groups.

The room temperature dark conductivity is dependent on several experimental parameters :

- the hydrogen partial pressure,

- the temperature of the substrates,

- the temperature of the dissociator.

The hydrogenation seems to be effective in the whole concentration range $x \leqq 0.50$, but for the highest tin contents, the temperature of crystallization is low and the thermal treatments do not modify the electrical behaviour.

The conductivity measurements also suggest a transition near $x=0.2$. For $x \geqq 0.2$, the slope of the conductivity versus $\frac{1}{T}$ corresponds to low activation energy, in the range $0.2-0.4 \mathrm{eV}$. In contrast, the transport results in the rich silicon side are consistent with extended states conduction. The activation energy is larger than $0.7 \mathrm{eV}$. The last domain is interesting because efficient gap for solar cells is $1.4 \mathrm{eV}$, value which is obtained in films containing less than $20 \%$ of tin [19].

These films are being further characterized by optical absorption and infrared absorption, the results of which will be described in a forthcoming paper. 


\section{References}

[1] Kaplan, D., Sol, N., Velasco, G. and Thomas, P. [10] Morimoto, A., Kataoka, T. and Schimizu, T., A., Appl. Phys. Lett. 33 (1978) 440.

Jpn. J. Appl. Phys. 23 (1984) L 812.
[11] Itozaki, H., Fujita, N., IgARAShi, T. and Hitot-

[2] Dellafera, P., Labusch, R. and Roscher, H. H., Philos. Mag. B 43 (1981) 169.

[3] Gangopadhyay, S., Iselborn, S., Rübel, H., Schröder, B. and Geiger, J., Philos. Mag. B 51 (1985) L 33.

[4] Grasso, V., Mezzasalma, A. M. and Neri, F., Solid State Commun. 41 (1982) 675.

[5] Shindo, M., Sato, S., Myokan, I., Mano, S. and Shibata, T., J. Non-Cryst. Solids 59-60 (1983) 747.

[6] Miller, D., Lutz, H., Wiesmann, H., Rock, E., Ghosh, A., Ramamoorthy, S. and Strongin, M., J. Appl. Phys. 49 (1978) 6192.

[7] Viturro, R. E. and Weiser, K., Philos. Mag. B 53 (1986) 93.

[8] Verié, C., Rochette, J. F. and Rebouillat, J. P., J. Physique 42 (1981) 667.

[9] Williamson, D. L. and Deb, S. K., J. Appl. Phys. 54 (1983) 2588. SuYANAGI, H., J. Non-Cryst. Solids 59-60 (1983) 589.

[12] Mahan, A. H., Williamson, D. L., Madan, A., Appl. Phys. Lett. 44 (1984) 220.

[13] Wenyuan, X., Yonbai, Y. and Changyan, L., $J$. Non-Cryst. Solids 77-78 (1985) 905.

[14] Vergnat, M., Marchal, G., Piecuch, M. and Gerl, M., Solid State Commun. 50 (1984) 237.

[15] FAY, J. A., Molecular thermodynamics (Addison Wesley 1965), ch. 14.

[16] Solomon, I., Dietl, T., Kaplan, D., J. Physique 39 (1978) 1241.

[17] Jones, K. M., Williamson, D. L. and Yacobi, B. G., J. Appl. Phys. 56 (1984) 1220.

[18] Williamson, D., Kerns, R. and Deb, S., J. Appl. Phys. 55 (1984) 2816.

[19] Mohamedi, A., D.E.A., University of Paris VI (1983) (unpublished). 